\title{
Molecular and phenetic characterization of the bacterial assemblage of Hot Lake, WA, an environment with high concentrations of magnesium sulphate, and its relevance to Mars
}

\author{
Brian R. Kilmer', Timothy C. Eberl', Brent Cunderla², Fei Chen ${ }^{3}$, Benton C. Clark ${ }^{4}$ \\ and Mark A. Schneegurt' \\ ${ }^{1}$ Department of Biological Sciences, Wichita State University, Wichita, KS USA e-mail: mark.schneegurt@wichita.edu \\ ${ }^{2}$ USDI-Bureau of Land Management, Wenatchee, WA, USA \\ ${ }^{3}$ Planetary Protection Group, Jet Propulsion Laboratory, NASA, Pasadena, CA, USA \\ ${ }^{4}$ Space Science Institute, Boulder, CO, USA
}

\begin{abstract}
Hot Lake (Oroville, WA) is an athalassohaline epsomite lake that can have precipitating concentrations of $\mathrm{MgSO}_{4}$ salts, mainly epsomite. Little biotic study has been done on epsomite lakes and it was unclear whether microbes isolated from epsomite lakes and their margins would fall within recognized halotolerant genera, common soil genera or novel phyla. Our initial study cultivated and characterized epsotolerant bacteria from the lake and its margins. Approximately 100 aerobic heterotrophic microbial isolates were obtained by repetitive streak-plating in high-salt media including either $10 \% \mathrm{NaCl}$ or $2 \mathrm{M}$ $\mathrm{MgSO}_{4}$. The collected isolates were all bacteria, nearly evenly divided between Gram-positive and Gram-negative clades, the most abundant genera being Halomonas, Idiomarina, Marinobacter, Marinococcus, Nesterenkonia, Nocardiopsis and Planococcus. Bacillus, Corynebacterium, Exiguobacterium, Kocuria and Staphylococcus also were cultured. This initial study included culture-independent community analysis of direct DNA extracts of lake margin soil using PCR-based clone libraries and 16S rRNA gene phylogeny. Clones assigned to Gram-positive bacterial clades ( $70 \%$ of total clones) were dominated by sequences related to uncultured actinobacteria. There were abundant Deltaproteobacteria clones related to bacterial sulphur metabolisms and clones of Legionella and Coxiella. These epsomite lake microbial communities seem to be divided between bacteria primarily associated with hyperhaline environments rich in $\mathrm{NaCl}$ and salinotolerant relatives of common soil organisms. Archaea appear to be in low abundance and none were isolated, despite near-saturated salinities. Growth of microbes at very high concentrations of magnesium and other sulphates has relevance to planetary protection and life-detection missions to Mars, where scant liquid water may form as deliquescent brines and appear as eutectic liquids.
\end{abstract}

Received 29 April 2013, accepted 13 June 2013

\section{Introduction}

Robotic spacecraft at Mars have found soils that are rich in salts, with a high abundance of sulphur compounds present as sulphates of $\mathrm{Mg}, \mathrm{Ca}$ and some Fe (Clark \& van Hart 1981; Clark 1993; Clark et al. 2005; Wänke et al. 2001; Altheide et al. 2009; McKay et al. 2013). Chlorides and perchlorates of Mg, $\mathrm{Na}$ or $\mathrm{Ca}$ are present, but are significantly less abundant than sulphates ( $\mathrm{S}: \mathrm{Cl}$ ratio of $4: 1$ ). Heavy brines could form as liquid water is generated from melting permafrost or by deliquescent salts (Cull et al. 2010; Lanza et al. 2010; McEwen et al. 2011; Möhlmann \& Thomsen 2011; McKay et al. 2013). Potential brines may be dominated by $\mathrm{MgSO}_{4}$, as $\mathrm{Ca}$ and $\mathrm{Fe}$ sulphates are sparingly soluble. To live in ephemeral moist areas on Mars, organisms may need to tolerate and grow at high salinities. Furthermore, the major ions may not be $\mathrm{Na}$ and $\mathrm{Cl}$, which dominate hypersaline environments on Earth, but rather $\mathrm{Mg}$ and sulphate. Understanding microbial life at high $\mathrm{MgSO}_{4}$ concentrations has relevance to the search for life on Mars and other celestial bodies such as Callisto, Enceladus, Europa and Ganymede, where subsurface oceans appear to be salty (Kargel et al. 2000; Marion et al. 2003; Hussmann et al. 2006; Mottl et al. 2007; Postberg et al. 2011).

Natural epsomite environments are rare and little experimental microbiology has been performed at saturating concentrations of $\mathrm{MgSO}_{4}$ (Handy 1916; Anderson 1958; Markovitz 1961; Markovitz \& Sylvan 1962; Boring et al. 1963; Hammer 1978, 1986; Laiz et al. 2000; Mandrioli \& SaizJimenez 2002; Nesbitt 2004; Hyde et al. 2007; Foster et al. 2010; Crisler et al. 2009, 2012; Lindemann et al. 2012). Prohibitively high epsomite concentrations have been advanced as potentially the most extreme of the near-surface conditions at Mars (Tosca et al. 2008). Our recent study 
screened a diverse collection of halotolerant bacteria from the Great Salt Plains (GSP) of Oklahoma for epsotolerance, the ability to grow at high $\mathrm{MgSO}_{4}$ concentrations (Crisler et al. 2012). The vast majority of these broadly halotolerant isolates, including Halomonas and Bacillus, grew in the presence of $2 \mathrm{M}$ $\mathrm{MgSO}_{4}$, even though the isolates were collected from salt flats rich in $\mathrm{NaCl}$, not $\mathrm{MgSO}_{4}$. None of the isolates were epsophilic, requiring high $\mathrm{MgSO}_{4}$ concentrations for growth, but none were halophilic, requiring high $\mathrm{NaCl}$ concentrations for growth, either (Schneegurt 2012). There was not a direct correspondence between the degree of halotolerance and the degree of epsotolerance in individual isolates. The current report extends these observations to bacterial isolates from $\mathrm{Hot}$ Lake, naturally rich in $\mathrm{MgSO}_{4}$, mainly as epsomite.

The potential of terrestrial microbes introduced into the Martian environment to grow and replicate as a function of temperature, salt concentration, and other environmental factors is relevant to the robotic exploration of Mars (NASA, 1980; DeVincenzi et al. 1996; Cooper et al. 2011). Given their low humidity $(40 \pm 5 \%)$, the Class $100 \mathrm{~K}$ clean rooms used as spacecraft assembly facilities (SAFs) may select for stress-tolerant microbes, particularly salinotolerant bacteria, those that potentially pose the greatest threats to planetary protection. Extensive studies of the microbial populations in SAFs have been performed previously using cultivation (Favero et al. 1968; Favero 1971; Foster \& Winans 1975; Puleo et al. 1977; Stieglmeier et al. 2009; Probst et al. 2010) and molecular strategies (Moissl et al. 2008; La Duc et al. 2009). Of the bacterial strains isolated from SAFs, some exhibited growth at $10 \% \mathrm{NaCl}$ (Venkateswaran et al. 2001, 2003a, b; La Duc et al. 2003; Link et al. 2003; Kempf et al. 2005). A wide variety of archaea have been observed in SAFs, some of which fall into groups associated with hypersaline environments (Moissl et al. 2008). Thus, the potential exists for contamination of spacecraft with halotolerant microbes in SAFs, however, salts in Mars soils are rich in $\mathrm{MgSO}_{4}$, not $\mathrm{NaCl}$, and there might not be a direct correspondence between tolerances to different salts.

The Canadian Plains is an area rich in athalassohaline lakes that have been used for mining sulphate salts including Glauber's salt and epsomite (Hammer 1978, 1986; Haynes \& Hammer 1978; Last \& Slezak 1988; Last \& Ginn 2005). A most unique feature of the lakes in this region is that 53 of 60 lakes were dominated by sulphate anions, exceeding 80 eq. $\%$ in more than two thirds of the lakes. The earliest microbiological examination of an epsomite lake was limited to descriptive work at Hot Lake, WA by Anderson (1958), who reported sulphidic green mats in deeper areas, suggestive of Chlorobium, Oscillatoria and Plectonema. Initial deep sequencing of Hot Lake mat communities has shown a predominance of cyanobacteria (Oscillatoria and Phormidium), Chromatia (Halochromatium and Thiohalocapsa), and purple non-sulphur bacteria (Roseobacter and Rhodovulum), along with other organisms involved in the sulphur cycle, Spirochaetes and Clostridia (Lindemann et al. 2012). Basque Lake, BC, a related series of epsomite playas, was the examined using IR spectroscopy to detect certain signatures of life (Hyde et al.
2007; Foster et al. 2010). While enrichment cultures for halotolerant microbes were positive, no isolates or microbiological analyses were reported.

The current work characterizes the microbial populations of Hot Lake using cultivation and molecular ecology techniques. A salinotolerant isolate collection was captured and curated through phylogenetic analysis of $16 \mathrm{~S}$ rRNA gene sequences. Isolates were further characterized by testing for epsotolerance and halotolerance. Random clone libraries of bacterial $16 \mathrm{~S}$ rRNA gene sequences were analysed phylogenetically. The microbial community at epsomite-rich Hot Lake is compared to that of the halite-rich GSP. This is placed in the context of Mars exploration and planetary protection. Preliminary accounts of this work have been presented previously (Crisler et al. 2010; Kilmer et al. 2011, 2012).

\section{Materials and methods}

\section{Site description and sample collection}

Water and lake margin soils ( $\sim 100 \mathrm{~g}$ from top $4 \mathrm{~cm}$ ) were collected from Hot Lake, WA (T. 40 N., R. 27 E., W.M., Section 7, SE $1 / 4$, Section 18, NE $1 / 4$, Okanogan County, WA; centered at 48 58'24.70" N 119 28'33.91" W; Fig. 1) in October 2009 using sterile tools and containers. Duplicate samples were collected, with one aliquot being frozen in the field and kept frozen during transport on dry ice for molecular work and the other aliquot being held fresh for live culture work. The level of the lake was relatively low at the time of sampling, the surface and pore waters were near saturation, margin soils were crusted with epsomite, and the $\mathrm{pH}$ was near 8 . The lake is surrounded by mature forest in a mountainous area at an elevation of $583 \mathrm{~m}$. The soils were predominantly a grey or black fine clay and silt, often with a strong sulphidic odour, and thin ice was present on the surface of the lake. Pore and lake water salinity was measured using a salinometer and found to be near saturation.

\section{Enrichment, isolation and characterization}

Direct plating, liquid enrichment and dilution plating were used to isolate halotolerant and epsotolerant microbes from Hot Lake waters and soils. The media used were based on SP medium (Caton et al. 2004), a nutrient-rich and moderately saline $(10 \%)$ medium containing per litre: $\mathrm{NaCl}, 98 \mathrm{~g}$; $\mathrm{KCl}, \quad 2.0 \mathrm{~g} ; \quad \mathrm{MgSO}_{4} \cdot 7 \mathrm{H}_{2} \mathrm{O}, \quad 1.0 \mathrm{~g} ; \mathrm{CaCl}_{2} \cdot 2 \mathrm{H}_{2} \mathrm{O}, \quad 0.36 \mathrm{~g}$; $\mathrm{NaHCO}_{3}, 0.06 \mathrm{~g} ; \mathrm{NaBr}, 0.23 \mathrm{~g} ; \mathrm{FeCl}_{3} \cdot 6 \mathrm{H}_{2} \mathrm{O}, 1.0 \mathrm{mg}$; trace minerals, $0.5 \mathrm{ml}$; Bacto tryptone, $5.0 \mathrm{~g}$; yeast extract, $10.0 \mathrm{~g}$; glucose, $1.0 \mathrm{~g}$; final $\mathrm{pH} 7.0$. This was prepared with either $10 \%$ $\mathrm{NaCl}, 10 \% \mathrm{MgSO}_{4}$ or $2 \mathrm{M} \mathrm{MgSO}_{4}$. Although these media were useful for liquid enrichments, agar plates with $2 \mathrm{M} \mathrm{MgSO}_{4}$ would not gel sufficiently, so isolates from liquid enrichments in this medium were transferred to medium with $10 \% \mathrm{NaCl}$. Enrichment cultures $(100 \mathrm{ml})$ were maintained as shakeflasks on a rotary shaking platform $(2.5 \mathrm{~cm}$ stroke dia) at $150 \mathrm{rpm}$ and incubated at 7,25 or $37^{\circ} \mathrm{C}$ before aliquots $(100 \mu \mathrm{l})$ were plated after 24 or $48 \mathrm{~h}$. For dilution plating, samples $(10 \mathrm{ml}$ or $10 \mathrm{~g})$ were diluted 10 -fold with appropriate media 


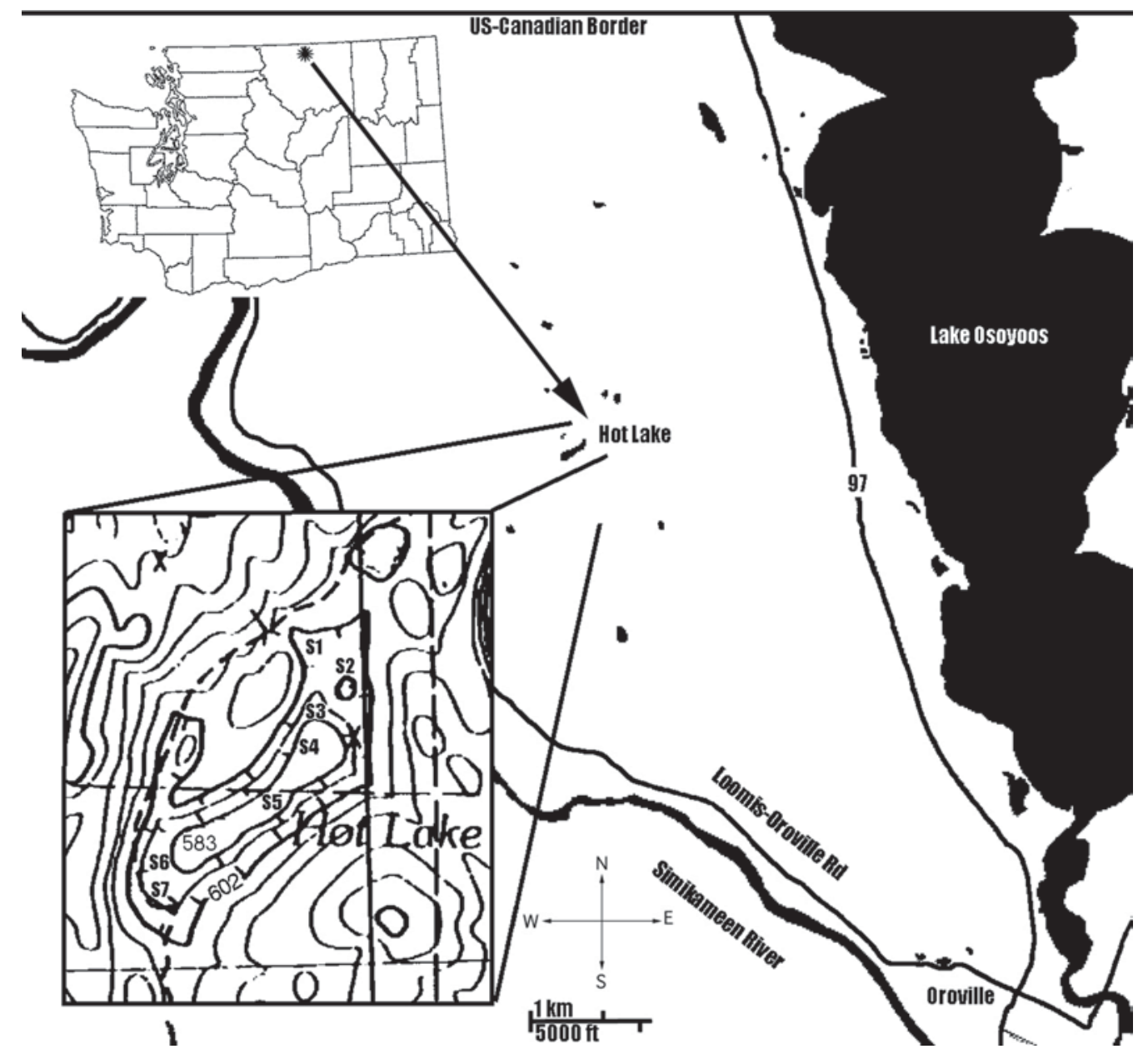

Fig. 1. Map of Hot Lake showing sampling sites for the current study marked as S1-S7. The altitude of the lake surface (583 m) is shown with topographical relief indicating that Hot Lake is in a depression surrounded by hills.

and serially diluted prior to plating. In some cases, soil or water aliquots (approximately $1 \mathrm{ml}$ or $0.5 \mathrm{~g}$ ) were spread directly onto the surface of plates. The plates were maintained at the appropriate temperature in a moist box and colonies were collected after several days. Colonies were marked and plates kept for several weeks during which time representatives of new colony types were harvested to capture slower growing organisms.

Colonies arising on plates were selected for isolation based on gross morphological and physiological features, including pigmentation, size, margin or rate of growth. Colonies were transferred to fresh SP agar plates with $10 \% \mathrm{NaCl}$ or $10 \%$ $\mathrm{MgSO}_{4}$ and isolated using the streak-plate method. Each isolate was subjected to at least five successive streak-platings to ensure clonal purity; the length of this process ranged among isolates from 2 to $16 \mathrm{wk}$. The isolates were curated as $50 \%$ glycerol stocks at $-80^{\circ} \mathrm{C}$ and as agar slants.

Isolates were Gram-stained using a Protocol Gram-staining kit (Fisher Diagnostics) following the manufacturer's instructions. SP medium composition was modified with different concentrations of $\mathrm{NaCl}$ or $\mathrm{MgSO}_{4}$ to measure salinity tolerances in liquid shake-tubes. Results are reported as the maximum and minimum conditions for growth. A positive threshold of 0.05 OD units was used and inconclusive tests were repeated.

\section{$P C R$, cloning and DNA sequencing}

Crude DNA extracts from each isolate were prepared using a freeze-thaw technique as described in Caton et al. (2004). Genomic DNA in the supernatant was the target of PCR amplification of nearly complete 16S rRNA gene fragments using bacterial primers (EUBPA: 5'-AGAGTTTGATCCTGGCTCAG-3' and EUBPH: 5'-AAGGAGGTGATCCAGCCGCA-3') (Edwards et al. 1989). PCRs were performed in a thermal cycler (Eppendorf Mastercycler) as $25 \mu \mathrm{l}$ reactions containing $0.2 \mu \mathrm{M}$ of each primer, $1 \mathrm{U}$ of ExTaq DNA polymerase and associated master mix (Takara) and $5 \mu \mathrm{l}$ of cell extract. DNA was denatured at $95^{\circ} \mathrm{C}$ for $2 \mathrm{~min}$, followed by 40 cycles of $95^{\circ} \mathrm{C}$ for $1 \mathrm{~min}, 50^{\circ} \mathrm{C}$ for $1 \mathrm{~min}$ and $72{ }^{\circ} \mathrm{C}$ for $1 \mathrm{~min}$, with a final $5 \mathrm{~min}$ extension at $72^{\circ} \mathrm{C}$. PCR amplicons were single-pass sequenced at the University of Kansas Biodiversity Institute using the EUBPA primer.

A metagenomic DNA extract was made directly from Hot Lake soil using the protocol of Bürgmann et al. (2001), with some modifications as previously described (Caton \& Schneegurt 2012). Briefly, cell breakage in soil samples is 




Fig. 2. Phylogenetic tree for Gram-negative bacteria from Hot Lake based on $16 \mathrm{~S}$ rRNA gene sequences. Bootstrap values greater than $50 \%$ are shown. A full tree with GenBank accession numbers, sample locations, and enrichment conditions can be found in Fig. S1.

performed by bead beating with CTAB detergent followed by organic extraction and precipitation with polyethylene glycol. The metagenomic extract was used as the template for PCR amplification of bacterial 16S rRNA gene sequences. Ten separate PCR amplicon populations were pooled following purification by band excision from a $2 \%$ agarose gel after electrophoresis. Clone libraries were generated from the pooled amplicons using a TOPO-TA blue-white cloning system in Escherichia coli (Invitrogen) following the manufacturer's instructions. More than 200 clones were randomly collected and inoculated into 96-well plates, with plasmid isolation and single-pass insert sequencing by a commercial vendor (Agencourt) using the EUBPA primer. Initial sequences were trimmed to remove remaining vector regions, leaving sequences of approximately $800 \mathrm{bp}$ for analysis. All sequences appear in GenBank with accession numbers KC705245 to KC705342 for cultured bacterial isolates and KC705343 to KC705470 for uncultured bacterial clones.

\section{Sequence analyses}

Sequences were automatically aligned using Clustal-W (Thompson et al. 1994) and then manually examined and 


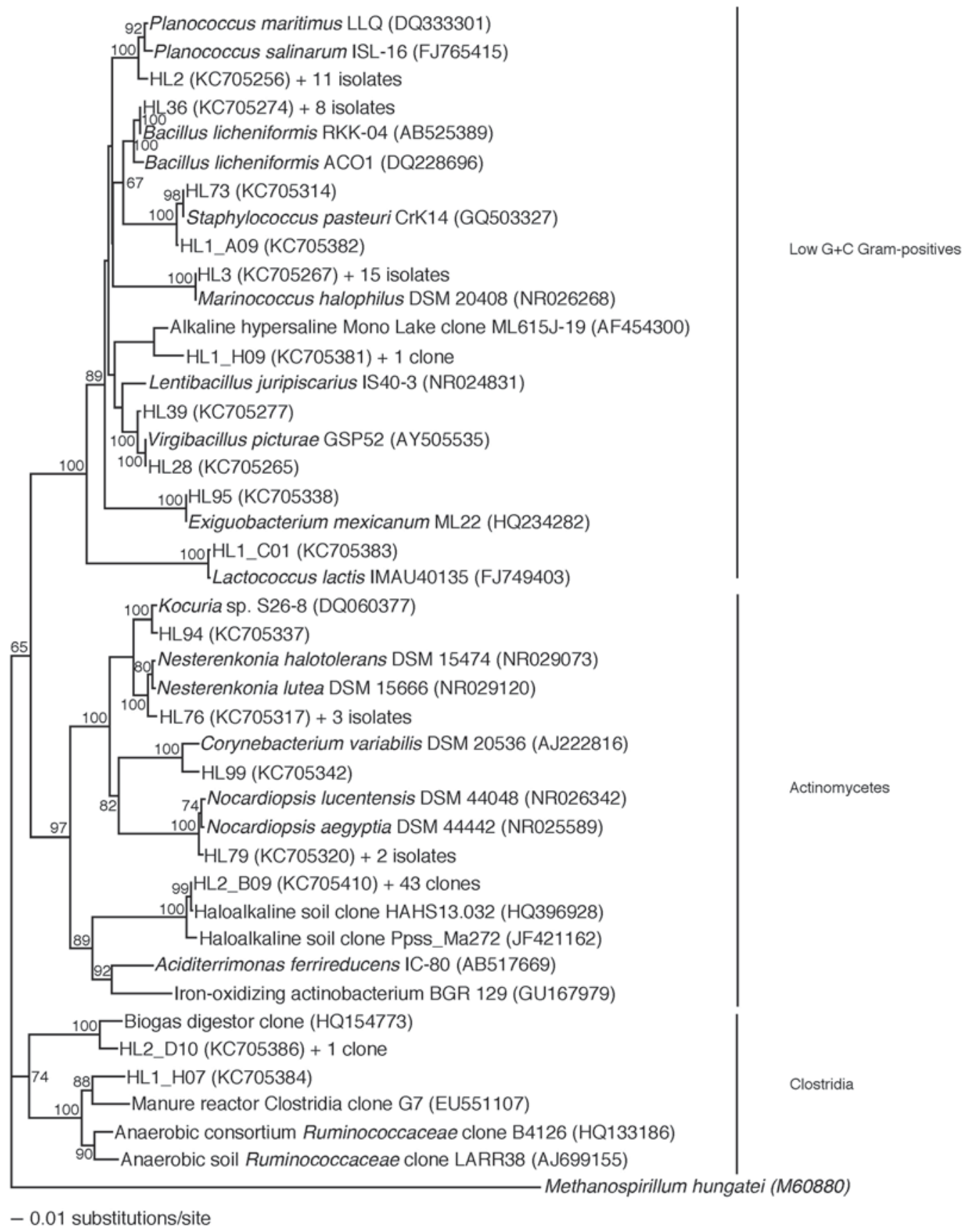

Fig. 3. Phylogenetic tree for Gram-positive bacteria from Hot Lake based on $16 \mathrm{~S}$ rRNA gene sequences. Bootstrap values greater than $50 \%$ are shown. A full tree with GenBank accession numbers, sample locations, and enrichment conditions can be found in Fig. S2.

trimmed in MacClade v4.08 (Sinauer Associates). Contextual 16S rRNA gene sequences were identified in GenBank using BLAST (Altschul et al. 1990) or by comparison with relevant literature. PAUP 4.0 b10 (Swofford 1998) generated phylogenetic trees using distance analysis with Jukes-Cantor rules and the neighbour-joining algorithm. Sequences were trimmed to equal lengths, with sequences less than $500 \mathrm{bp}$ removed, and positions with gaps and ambiguous bases ignored, giving 500600 positions for analysis. Bootstrap analysis was used to assess the relative support for each branch with a total of 100 replicates conducted heuristically using the distance-based neighbour-joining algorithm and the nearest-neighbour-interchange algorithm in PAUP. The trees were rooted using Methanospirillum hungatei as the functional outgroup. Putative chimeras (approximately 15\% of the sequences) were identified through iterative analyses using Pintail within MOTHUR (Schloss et al. 2009), manually examined, and removed if necessary. Full phylogenetic trees with GenBank accession numbers can be found in supplementary materials (Figs. S1-S3) (available at http://journals.cambridge.org/IJA). Distance files were further analysed using the MOTHUR statistical package to determine Chaol estimators, Simpson 


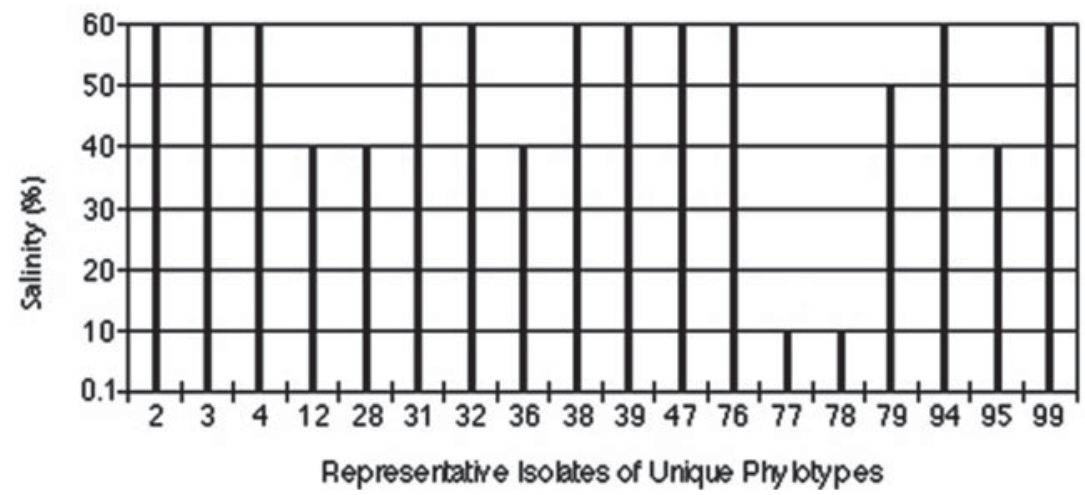

Fig. 4. Epsotolerance of Hot Lake bacterial isolates. Bars indicate the ranges permissible for growth.

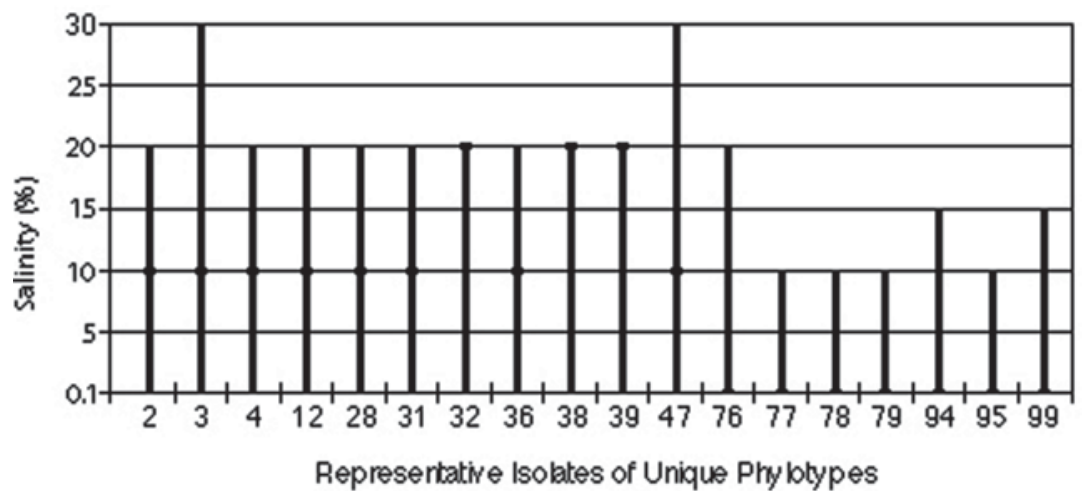

Fig. 5. Halotolerance of Hot Lake bacterial isolates. Bars indicate the ranges permissible for growth and the optimal salinities for growth are indicated by closed squares.

indexes, non-parametric Shannon indexes, rarefaction curves and OTUs at various levels of sequence similarity. Library comparisons were made using BLAST.

\section{Results}

\section{Collection and identification of bacterial isolates}

All seven soil and water samples provided bacterial isolates, with the soil samples from Sites 2, 4 and 7 each providing approximately $25 \%$ of the collection. Nearly 100 aerobic heterotrophic bacterial isolates were acquired from Hot Lake by dilution plating and repetitive streaking. Most isolates were obtained from enrichment cultures at room temperature in SP medium supplemented with $10 \% \mathrm{NaCl}$. Approximately a third of the isolates were obtained at 30 or $37^{\circ} \mathrm{C}$ in SP medium supplemented with $10 \%$ or $2 \mathrm{M} \mathrm{MgSO}_{4}$. The enrichment medium and temperature and the sampling site for each isolate are given in the full phylogenetic trees (Figs. S1 and S2). Representatives of the most common colony types from all seven of the soil and water samples were collected, increasing the degree of duplication in the overall collection. Phylogenetic analysis was performed on 16S rRNA gene sequences to identify each isolate (Figs. 2, 3, S1 and S2).

Serial dilution plating on SP medium with $10 \%$ salinity was used to isolate the most abundant culturable microbes in Hot
Lake samples. Fourteen isolates were obtained from the highest positive dilutions $\left(10^{6}-10^{8}\right)$ of these series. Halomonas appears to be the most abundant culturable genera; isolated (44 total isolates) from all seven soil and water samples, with six isolates collected from the highest positive dilution plates (HL 12, 19, 22, 23, 24, 33 and 75). The other abundant Gram-negative genera observed on dilution plates were Idiomarina (HL78) and Marinobacter (HL77). Low G+C Gram-positive Marinococcus were abundant and were isolated from Sites 2, 4 and 7 (17 total isolates), with three isolates collected from the highest positive dilution plates (HL 9, 25 and 27). The other abundant Gram-positive genera observed on dilution plates were low $\mathrm{G}+\mathrm{C}$ Planococcus (HL1) and the actinomycetes Nocardiopsis (HL79) and Nesterenkonia (HL76). Bacillus species were represented by nine isolates that were all enriched at 30 or $37^{\circ} \mathrm{C}$, but no Bacillus were isolated from the highest positive dilution plates. In addition to these abundant genera, isolates were obtained from Corynebacterium, Exiguobacterium, Kocuria, Staphylococcus and Virgibacillus. No archaea or distinctly red microbes were isolated from Hot Lake despite enrichments in high-salt media at $37^{\circ} \mathrm{C}$. While not described in the current work, a number of cyanobacteria and fungi were cultured at high salinities and anaerobic bottles were positive for fermenters and sulphate-reducers at $10 \%$ $\mathrm{NaCl}$ and $2 \mathrm{M} \mathrm{MgSO}_{4}$. 




Fig. 6. Phylogenetic tree for Chloroflexi and unclassified bacteria from Hot Lake based on 16S rRNA gene sequences. Bootstrap values greater than $50 \%$ are shown. A full tree with GenBank accession numbers, sample locations, and enrichment conditions can be found in Fig. S3.

\section{Epsotolerance and halotolerance in bacterial isolates}

The Hot Lake isolate collection was screened for growth tolerance to high $\mathrm{NaCl}$ and $\mathrm{MgSO}_{4}$ concentrations. Nearly all $(82 \%)$ of the bacterial isolates from Hot Lake grew at $50 \%$ $\mathrm{MgSO}_{4}$ (approximately $2 \mathrm{M}$ ). More than half (58\%) grew at $60 \% \mathrm{MgSO}_{4}$, near saturation. Broad epsotolerance was expected at Hot Lake given its seasonal changes in salinity with snowmelt and summer evaporation. Salinity tolerance ranges of representative isolates from each Hot Lake phylotype are shown in Fig. 4 and the results for each isolate are given in
Table S1(available at http://journals.cambridge.org/IJA). It is interesting to note that some isolates, such as HL 77 and 78, exhibited poor or no growth above $10 \% \mathrm{MgSO}_{4}$. No epsophilic organisms, requiring high $\mathrm{MgSO}_{4}$ concentrations for growth, have been isolated.

The Hot Lake isolates showed remarkable growth tolerance to high $\mathrm{NaCl}$ concentrations, although their natural environment is not rich in chlorides or monovalent cations. All isolates grew at $10 \% \mathrm{NaCl}$ and three-quarters of the isolates grew at $20 \%$ salinity $(\sim 3.5 \mathrm{M} \mathrm{NaCl})$. Note that the water activity of $20 \% \mathrm{NaCl}(0.82)$ 
Table 1. Diversity analyses of Hot Lake bacterial 16S rRNA gene sequences

\begin{tabular}{lllll}
\hline & \multicolumn{3}{l}{ Level of sequence identity } \\
\cline { 2 - 5 } Parameter & $99 \%$ & $97 \%$ & $94 \%$ & $88 \%$ \\
\hline OTUs & 84 & 65 & 55 & 47 \\
Coverage & 0.79 & 0.77 & 0.77 & 0.77 \\
Chaol & & & & \\
$\quad$ Average & 182 & 108 & 84 & 68 \\
$\quad 95 \%$ CI & $130-290$ & $83-165$ & $66-131$ & $54-106$ \\
$\quad$ Shannon index $(\mathrm{H})$ & & & & \\
$\quad$ Average & 4.11 & 3.71 & 3.42 & 3.19 \\
$\quad H / H_{\text {max }}\left(E_{\mathrm{H}}\right)$ & 0.76 & 0.69 & 0.63 & 0.60 \\
Simpson index $(D)$ & 0.048 & 0.062 & 0.080 & 0.092 \\
\hline
\end{tabular}

is substantially lower than that of saturated $\mathrm{MgSO}_{4}(0.90)$. This is due in part to limited dissociation of $\mathrm{MgSO}_{4}$ in solution. Some of the isolates $(16 \%)$, predominantly Marinococcus, showed growth at $30 \% \mathrm{NaCl}$, near saturation. Salinity tolerance ranges of representative isolates from each Hot Lake phylotype are shown in Fig. 5 and the results for each isolate are given in Table S1. There was not always a direct correspondence between the epsotolerance and halotolerance of individual isolates as exemplified by HL 94 and 99 which grow at $60 \% \mathrm{MgSO}_{4}$ but do not grow above $15 \% \mathrm{NaCl}$ (cf. Figs. 4 and 5).

\section{Culture-independent clone library}

A bacterial 16S rRNA gene clone library was prepared from direct DNA extracts of the same soil sample (Site 7) that was the source of many isolates from the cultivation campaign. To reduce biases in the library, the amplicons from ten separate PCRs were combined in the cloning reaction. Approximately 200 random bacterial 16S rRNA gene clones were sequenced. Chimeras were removed (Huber et al. 2004) and a few sequences were too short for analysis. Overall clustering of major monophyletic groups is shown in Figs. 2, 3, 6 and S1-S3 and followed expected patterns. None of the sequences on the Unclassified tree (Figs. 6 and S3) were represented by cultured isolates; only clones from direct DNA extracts were assigned to these clades. A similar approach was applied using archaeal 16S rRNA gene primers (Caton et al. 2009). Although archaeal sequences could be detected by PCR, these appear to be in low abundance and a clone library was not pursued.

\section{Estimation of diversity and coverage}

The results of statistical estimates (Schloss et al. 2009) of species richness, evenness, and the efficiency of species collection for the culture-independent clone library are given in Table 1 and Fig. 7. The data are presented at several levels of sequence identity, reflecting commonly used thresholds for the taxonomic levels of strain (99\%), species (97\%), genus $(94 \%)$ and division $(88 \%)$. The number of OTUs increases at higher levels of sequence identity as expected. Using a threshold of $99 \%$ sequence identity, 84 OTUs were identified within the bacterial sequences. Good's coverage values were relatively high and consistent at all levels of identity (Schloss et al. 2009).
Rarefaction curves are presented in Fig. 7. None of these curves levels off, indicating that more sampling is needed to describe this community. Chaol estimates were used to project the total number of OTUs at different levels of sequence identity (Table 1). At the 99\% sequence identity level, 182 OTUs were predicted, while 84 OTUs were predicted at the $97 \%$ sequence identity level. It is estimated that 46,60 and $65 \%$ of the bacterial diversity was sampled at 99, 97 and 94\% sequence identity, respectively. The Shannon and Simpson indices both suggest that bacterial diversity increases at higher levels of sequence identity. The distribution of bacterial taxa in the library is relatively even since a measure of evenness, $H / H_{\text {max }}$, is relatively high across all levels of identity. No equivalent epsomite environment has been described previously for direct comparison. The diversity estimates of the bacterial community at Hot Lake are similar to those of previous studies of environments rich in $\mathrm{NaCl}$ (Caton et al. 2004; Wani et al. 2006; Mesbah et al. 2007; ValenzuelaEncinas et al. 2009).

\section{Phylogenetic groups recovered}

Phylogenetic trees based on the 16S rRNA clone library were generated that included sequences from cultured and uncultured bacteria obtained from the GenBank database (Figs 2, 3, 6 and S1-S3). Initial BLAST analyses were used to direct searches for rRNA gene sequences closely related to clones derived from Hot Lake. Clones from Gram-positive bacteria represented $40 \%$ of the library. Of these, clones related to uncultured actinomycetes dominated (>85\%). Bacillus, Clostridia, Lactococcus and Staphylococcus also were detected. Staphylococcus is one of the few genera both cultivated and detected in the clone library.

Clones related to Gram-negative bacteria represented approximately $30 \%$ of the library. Legionella and Coxiella represented nearly half of the Gram-negative clones. Deltaproteobacteria were abundant in the clone library. This division is rich in sulphate-reducing bacteria that might be expected in an environment saturated in sulphate salts. Halothiobacillus, a purple sulphur bacterium in the Gammaproteobacteria, was observed and is presumably involved in autotrophic metabolism at Hot Lake. Clones related to Acidovorax, Erythrobacter and Lysobacter also were detected. Although Halomonas dominated the isolate collection, these were not detected in the clone library.

A number of clones clustered only with rRNA sequences from uncultured bacteria, some of which belong to candidate divisions. Approximately half of these clones clustered with members of candidate division TM6. A group of seven clones including HL2_C08 were not clearly related to known taxa. Clones related to TM7, OP10 and OP11 also were detected. A group of clones were related to the photosynthetic Chloroflexi.

\section{Comparison of clone libraries from Hot Lake and JPL SAFS}

A composite library of sequences obtained from SAF samples at JPL was compared to 277 sequences in the Hot Lake collection using BLAST. Approximately one third of the Hot Lake sequences matched the JPL SAF library at the genus 


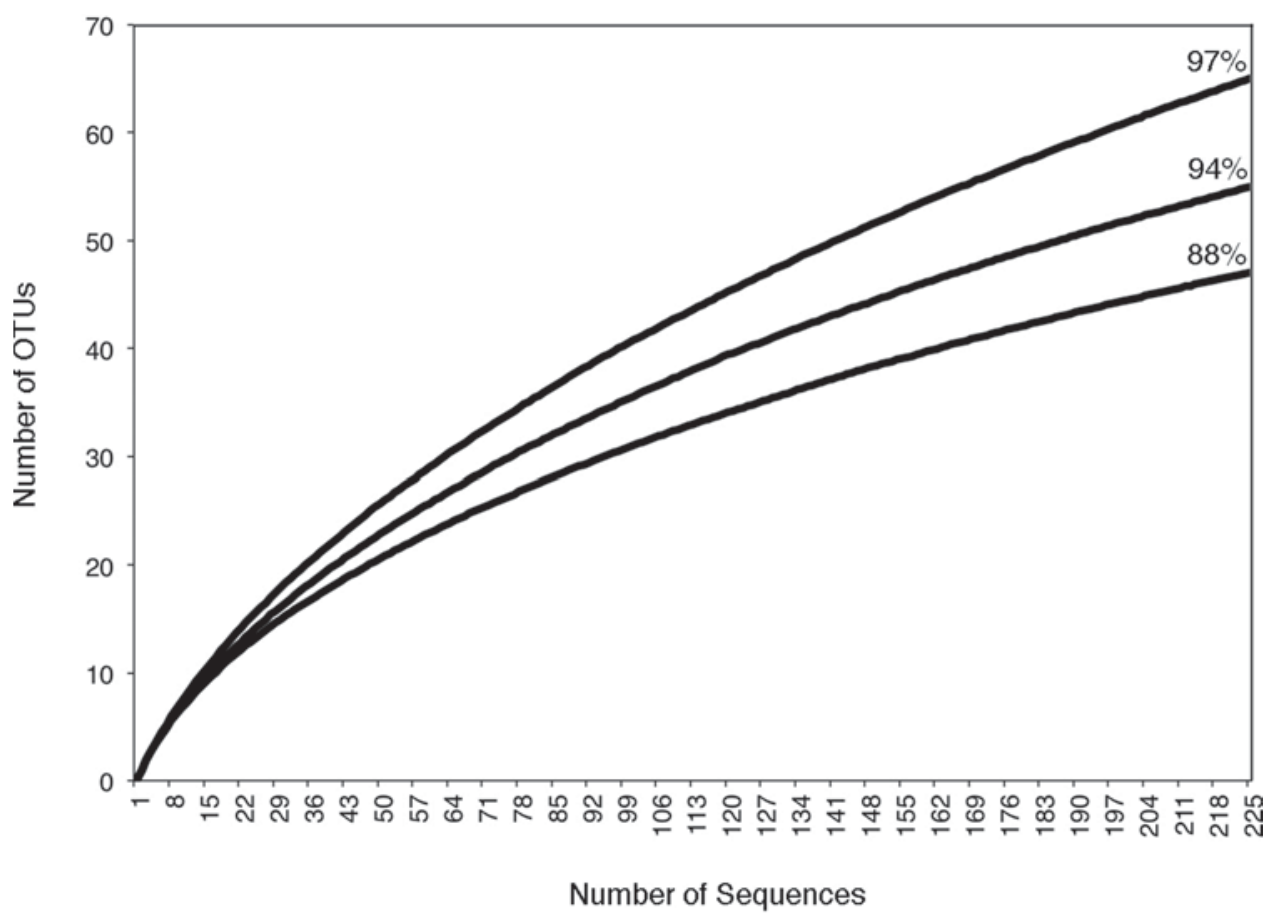

Fig. 7. Rarefaction curves based on bacterial 16S rRNA gene sequences from Hot Lake. The curves represent different levels of sequence identity.

( $\geq 94 \%$ identity) level. At the species level ( $\geq 97 \%$ identity), approximately $13 \%$ of the Hot Lake sequences matched the JPL SAF library. The best matches were predominantly with Hot Lake isolates, especially Bacillus, Halomonas, Kocuria and Nocardiopsis. All Hot Lake sequences with less than $88 \%$ identity (division level) with the JPL SAF library were from clone libraries, not isolates. Both collections appear to be rich in microbes commonly found in soils including actinomycetes. An initial comparison with a composite sequence library from ESA SAFs showed less overlap with the Hot Lake collection as the ESA collection appeared to be richer in microbes typically associated with humans.

\section{Discussion}

Our recent paper reported that broad epsotolerance to $2 \mathrm{M}$ $\mathrm{MgSO}_{4}$ is common in halotolerant bacteria from the GSP (Crisler et al. 2012). Now we show that a natural environment with saturating concentrations of $\mathrm{MgSO}_{4}$ supports a diverse microbial community with broad epsotolerance and halotolerance. Greater halotolerance was generally observed in the GSP isolates than in Hot Lake isolates. Reciprocally, greater epsotolerance was generally observed in Hot Lake isolates than in GSP isolates. Within highly salinotolerant organisms apparently there is ionic specialization that concurs with their natural habitats to some extent. Nonetheless, substantial halotolerance was observed in isolates from Hot Lake, which does contain high concentrations of $\mathrm{NaCl}$. It should be noted that while the Hot Lake bacterial isolates have broad halotolerance and epsotolerance, none were halophiles or epsophiles that require high salts for growth. At the GSP, the predominance of halotolerant organisms over halophilic organisms was suggested to have resulted from the rapidly changing salinity that accompanies flooding rain events and subsequent drying. At Hot Lake, broad salinotolerance may be a reflection of seasonal dilution with snowmelt and evaporative concentration in the warmer months.

Since no epsomite lake had been examined microbiologically, it was unknown whether bacterial isolates would be identified as those typically associated with hyperhaline environments, salinotolerant relatives of nearby forest soil bacteria, or bacteria endemic to epsomite environments. Most of the cultivated isolates and many of the molecular clones from Hot Lake were assigned to taxa commonly observed in hyperhaline environments such as Bacillus, Halomonas and Marinococcus. In contrast, Hot Lake yielded a number of actinomycetes that are not as widely reported from hyperhaline environments. No actinomycetes were isolated from the GSP, for example, using similar techniques. Actinomycetes are a numerically important cluster of bacterial clones from the culture-independent library. Initial deep sequencing of Hot Lake samples confirms the abundance of actinomycetes, in addition to a high number of Clostridia (Vaishampayan and Chen, unpublished). In fact, anaerobic bacteria appear to be common at Hot Lake with abundant sulphate-reducing bacteria in the clone library. Isolates and clones from the CFB group were abundant at the GSP, but absent in the Hot Lake isolate and clone collections. Some CFB group clones were detected in initial deep sequencing of Hot Lake. A significant portion of the clone library was assigned to unaffiliated taxa for which isolates have not been reported. While the isolate collection was dominated by bacteria 
typically associated with hyperhaline locations, the clone library more resembled a common soil community with abundant actinomycetes, Bacillus, Clostridia, Legionella and Acidovorax.

Perhaps the most surprising feature of the microbial community at Hot Lake was the near absence of archaea. In hyperhaline environments, archaea often dominate near saturating salinities. Archaeal 16S rRNA gene sequences were detected in certain Hot Lake samples by PCR, but these were in low abundance (Kilmer et al. 2012). One explanation is that many haloarchaea are extreme halophiles that require at least $1.5 \mathrm{M} \mathrm{NaCl}$ for growth (Mohr \& Larsen 1963; Schneegurt 2012). This salt requirement apparently cannot be fulfilled by other salts (Mullakhanbhai \& Larsen 1975; Onishi et al. 1980; Vreeland \& Martin 1980). Hot Lake does not have high concentrations of $\mathrm{NaCl}$; so extremely halophilic archaea would not be expected to grow there. The archaea detected in sediments may be salinotolerant methanogens rather than haloarchaea.

It is becoming clear that epsotolerance is more widespread than one might expect given the limited distribution of epsomite environments on Earth. Initial studies of garden soils found a measurable number of epsotolerant and halotolerant microbes (Porazka et al. 2011). This includes soil samples taken near the SAFs at JPL, increasing the potential for contamination of spacecraft with microbes tolerant to high $\mathrm{MgSO}_{4}$. Furthermore, initial analyses indicate that epsotolerant bacteria can be isolated from SAFs and clones from related taxa were detected using molecular means (Kilmer et al. 2012). Epsotolerance may increase the likelihood that a microbial contaminant could survive after a heatproducing crash landing of a spacecraft. Special habitats on Mars where liquid water is present may be heavy brines rich in sulphates of magnesium, calcium and iron, perhaps as eutectic liquids produced through deliquescence. Brines of perchlorate salts may be present in the north polar regions (McKay et al. 2013). Initial screening of bacterial isolates from Hot Lake and the GSP has shown considerable tolerance to perchlorates, in some cases, growing at $15 \%$ sodium or magnesium perchlorate (Mai et al. 2012). A better understanding of terrestrial microbes growing under these conditions will impact life detection and sample return missions to Mars and other celestial bodies.

\section{Acknowledgements}

The authors are grateful for the preliminary and supportive work performed by Ashkaun Adib, James Crisler, John Dille, Felicia Giok, Jessica Pham, Kyle Rowe, Hutan Vahdat, Emily Winn and Lana Zayed. We are grateful to Stephen Lindemann (Pacific Northwest National Laboratory) for collecting Hot Lake samples and sharing related data. We thank Fadi Aramouni (Kansas State University) for performing water activity measurements, Christine Moissl-Eichinger (University of Regensburg) for sharing the ESA SAF bacterial 16S rRNA gene sequence database, and Parag Vaishampayan (NASA JPL) for comparing genetic libraries.
This work was supported by awards from NASA ROSES Planetary Protection (PPR) and Kansas NASA EPSCoR. Additional support was provided by awards from NIH NCRR NIGMS KINBRE.

\section{Supplementary materials}

For supplementary material for this article, please visit http:// dx.doi.org/10.1017/S1473550413000268.

\section{References}

Altheide, T., Chevrier, V., Nicholson, C. \& Denson, J. (2009). Experimental investigation of the stability and evaporation of sulfate and chloride brines on Mars. Earth Planet. Sci. Lett. 282, 69-78.

Altschul, S.F., Gish, W., Miller, W., Myers, E.W. \& Lipman, D.J. (1990). Basic local alignment search tool. J. Mol. Biol. 215, 403-410.

Anderson, G.C. (1958). Some limnological features of a shallow saline meromictic lake. Limnol. Oceanogr. 3, 259-270.

Boring, J., Kushner, D.J. \& Gibbons, N.E. (1963). Specificity of the salt requirement of Halobacterium cutirubrum. Can. J. Microbiol. 2, 143-154.

Bürgmann, H., Pesaro, M., Widmer, F. \& Zeyer, J. (2001). A strategy for optimizing quality and quantity of DNA extracted from soil. J. Microbiol. Methods 45, 7-20.

Caton, I.R. \& Schneegurt, M.A. (2012). Culture-independent analysis of the soil bacterial assemblage at the Great Salt Plains of Oklahoma. J. Basic Microbiol. 52, 16-26.

Caton, T.M., Witte, L.R., Ngyuen, H.D., Buchheim, J.A., Buchheim, M.A. \& Schneegurt, M.A. (2004). Halotolerant aerobic heterotrophic bacteria from the Great Salt Plains of Oklahoma. Microb. Ecol. 48, 449-462.

Caton, T.M., Caton, I.R., Witte, L.R. \& Schneegurt, M.A. (2009). Archaeal diversity at the Great Salt Plains of Oklahoma described by cultivation and molecular analyses. Microb. Ecol. 58, 519-528.

Clark, B.C. (1993). Geochemical components in Martian soil. Geochim. Cosmochim. Acta 57, 4575-4581.

Clark, B.C. \& van Hart, D. (1981). The salts of Mars. Icarus 45, 370-378.

Clark, B.C., Morris, R.V., McLennan, S.M., Gellert, R., Jolliff, B., Knoll, A.H., Squyres, S.W., Lowenstein, T.K., Ming, D.W., Tosca, N.J. et al. (2005). Chemistry and mineralogy of outcrops at Meridiani Planum. Earth Planet. Sci. Lett. 240, 73-94.

Cooper, M., La Duc, M.T., Probst, A., Vaishampayan, P., Stam, C., Benardini, J.N., Piceno, Y.M., Anderson, G.L. \& Venkateswaran, K. (2011). Comparison of innovative molecular approaches and standard spore assays for assessment of surface cleanliness. Appl. Environ. Microbiol. 77, 5438-5444.

Crisler, J.D., Newville, T.M. \& Schneegurt, M.A. (2009). Bacterial growth at concentrations of magnesium sulfate found in Martian soils. Trans. KS Acad. Sci. 112, 136.

Crisler, J.D., Kilmer, B.R., Rowe, K., Cunderla, B., Madu, B.E. \& Schneegurt, M.A. (2010). Isolation and characterization of microbes from Basque Lake, BC, and Hot Lake, WA, environments with high magnesium sulfate concentrations. Trans. KS Acad. Sci. 113, 122-123.

Crisler, J.D., Newville, T.M., Chen, F., Clark, B.C. \& Schneegurt, M.A. (2012). Bacterial growth at the high concentrations of magnesium sulfate found in Martian soils. Astrobiology 12, 98-106.

Cull, S.C., Arvidson, R.E., Catalano, J.G., Ming, D.W., Morris, R.V., Mellon, M.T. \& Lemmon, M. (2010). Concentrated perchlorate at the Mars Phoenix landing site: evidence for thin film liquid water on Mars. Geophys. Res. Lett. 37, L22203, doi: 10.1029/2010GL045269.

DeVincenzi, D.L., Stabekis, P. \& Barengoltz, J. (1996). Refinement of planetary protection policy for Mars missions. Adv. Space Res. 18, 311-316.

Edwards, U., Rogall, H., Blöcker, H., Emde, M. \& Böttger, E.C. (1989). Isolation and direct complete nucleotide determination of entire genes. 
Characterization of a gene coding for $16 \mathrm{~S}$ ribosomal RNA. Nucl. Acids Res. 17, 7843-7853.

Favero, M.S. (1971). Microbiologic assay of space hardware. Environ. Biol. Med. 1, 27-36.

Favero, M.S., Puleo, J.R., Marshall, J.H. \& Oxborrow, G.S. (1968). Comparison of microbial contamination levels among hospital operating rooms and industrial clean-rooms. Appl. Microbiol. 16, 480-486.

Foster, I.S., King, P.L., Hyde, B.C. \& Southam, G. (2010). Characterization of halophiles in natural $\mathrm{MgSO}_{4}$ salts and laboratory enrichment samples: astrobiological implications for Mars. Planet. Space Sci. 58, 599-615.

Foster, T.L. \& Winans, L. (1975). Psychrophilic microorganisms from areas associated with the Viking spacecraft. Appl. Microbiol. 30, 546-550.

Hammer, U.T. (1978). The saline lakes of Saskatchewan. III. Chemical characterization. Int. Rev. Hydrobiol. 63, 311-335.

Hammer, U.T. (1986). Saline Lake Ecosystems of the World. Junk, Dordrecht.

Handy, F.M. (1916). An Investigation of the Mineral Deposits of Northern Okanogan County. Bulletin 100, State College of Washington, Pullman.

Haynes, R.C. \& Hammer, U.T. (1978). The saline lakes of Saskatchewan. IV. Primary production by phytoplankton in selected saline ecosystems. Int. Rev. Hydrobiol. 63, 337-351.

Huber, T., Faulkner, G. \& Hugenholtz, P. (2004). BELLEROPHON: a program to detect chimeric sequences in multiple alignments. Bioinformatics 20, 2317-2319.

Hussmann, H., Sohl, F. \& Spohn, T. (2006). Subsurface oceans and deep interiors of medium-sized outer planet satellites and large trans-neptunian objects. Icarus 185, 258-273.

Hyde, B.C., Foster, I.S., King, P.L., Southam, G. \& Nushaj, D. (2007). Limits of detection for life on Mars: an example using IR spectroscopy of sulfate salts and halophiles from lakes in British Columbia, Canada. Lunar Planet. Sci. XXXVIII, 2278-2279.

Kargel, J.S., Kaye, J.Z., Head, J.W. III, Marion, G.M., Sassen, R., Crowley, J.K., Ballesteros, O.P., Grant, S.A. \& Hogenbloom, D.L. (2000). Europa's crust and ocean: origin, composition, and the prospects for life. Icarus 148, 226-265.

Kempf, M.J., Chen, F., Kern, R. \& Venkateswaran, K. (2005). Recurrent isolation of hydrogen peroxide-resistant spores of Bacillus pumilus from a spacecraft assembly facility. Astrobiology 5, 391-405.

Kilmer, B.R., Eberl, T., Rowe, K., Cunderla, B. \& Schneegurt, M.A. (2011). Characterization of the microbial assemblage from the saturating magnesium sulfate environment of Hot Lake, WA. Trans. KS Acad. Sci. $115,163$.

Kilmer, B.R., Eberl, T.C., Crisler, J.D., Cunderla, B., Madu, B.E. \& Schneegurt, M.A. (2012). Cultivation and molecular analysis of the microbial community in epsomite lakes of the Pacific Northwest. In 112th General Meeting of the American Society for Microbiology.

La Duc, M.T., Nicholson, W., Kern, R. \& Venkateswaran, K. (2003). Microbial characterization of the Mars Odyssey spacecraft and its encapsulation facility. Environ. Microbiol. 5, 977-985.

La Duc, M.T., Osman, S., Vaishampayan, P., Piceno, Y., Anderson, G., Spry, J.A. \& Venkateswaran, K. (2009). Comprehensive census of bacteria in clean rooms by using DNA microarray and cloning methods. Appl. Environ. Microbiol. 75, 6559-6567.

Laiz, L., Recio, D., Hermosin, B. \& Saiz-Jimenez, C. (2000). Microbial communities in salt efflorescences. In Of Microbes and Art: The Role of Microbial Communities in the Degradation and Protection of Cultural Heritage, ed. Ciferri, O., Tiano, P. \& Mastromei, G., pp. 77-88. Kluwer, New York.

Lanza, N.L., Meyer, G.A., Okubo, C.H., Newson, H.E. \& Wiens, R.C. (2010). Evidence for debris flow gully formation initiated by shallow subsurface water on Mars. Icarus 205, 103-112.

Last, W.M. \& Ginn, F.M. (2005). Saline systems of the Great Plains of western Canada: an overview of the limnogeology and paleolimnology. Saline Syst. 1, 10.

Last, W.M. \& Slezak, L.A. (1988). The salt lakes of western Canada: a paleolimnological overview. Hydrobiologia 158, 310-316.

Lindemann, S.R., Moran, J.J., Dohnalkova, A., Kim, Y., Kennedy, D.W., Stolyar, S., Maors, P.D., Wiley, H., Konopka, A.E. \& Fredrickson, J.K.
(2012). Microbial Diversity and biogeochemical function of the phototrophic microbial mats of epsomitic Hot Lake, WA. Microsc. Microanal. S2, 10-11.

Link, L., Sawyer, J., Venkateswaran, K. \& Nicholson, W. (2003). Extreme spore UV resistance of Bacillus pumilus isolates obtained from an ultraclean spacecraft assembly facility. Microb. Ecol. 47, 159-163.

Mai, T.T., Nosova, A.O. \& Schneegurt, M.A. (2012). Bacterial growth in perchlorate salts at concentrations found in soils on Mars. Trans. KS Acad. Sci. 115, 64 .

Mandrioli, P. \& Saiz-Jimenez, C. (2002). Biodeterioration: macromonitoring and microeffects on cultural heritage and the potential benefits of research to society. EC Advanced Study Course Technical Notes, Sessions 7-8, pp. $1-5$

Marion, G.M., Fritsen, C.H., Eicken, H. \& Payne, M.C. (2003). The search for life on Europa: limiting environmental factors, potential habitats, and Earth analogues. Astrobiology 3, 785-811.

Markovitz, A. (1961). Method for the selection of bacteria that synthesize uronic acid-containing polysaccharides. J. Bacteriol. 82, 436-441.

Markovitz, A. \& Sylvan, S. (1962). Effect of sodium sulfate and magnesium sulfate on heteropolysaccharide synthesis in gram-negative soil bacteria. J. Bacteriol. 83, 483-489.

McEwen, A.S., Ojha, L., Dundas, C.M., Mattson, S.S., Byrne, S., Wray, J.J., Cull, S.C., Murchie, S.L., Thomas, N. \& Gulick, V.C. (2011). Seasonal flows on warm Martian slopes. Science 333, 740-743.

McKay, C.P., Stoker, C.R., Glass, B.J., Davé, A.I., Davila, A.F., Heldmann, J.L., Marinova, M.M., Fairen, A.G., Quinn, R.C., Zacny, K.A. et al. (2013). The Icebreaker Life Mission to Mars: a search for biomolecular evidence of life. Astrobiology 13, 334-354.

Mesbah, N.M., Abou-El-Ela, S.H. \& Wiegel, J. (2007). Novel and unexpected prokaryotic diversity in water and sediments of the alkaline, hypersaline lakes of the Wadi An Natrun, Egypt. Microb. Ecol. 54, 598-617.

Möhlmann, D. \& Thomsen, K. (2011). Properties of cryobrines on Mars. Icarus 212, 123-130.

Mohr, V. \& Larsen, H. (1963). On the structural transformations and lysis of Halobacterium salinarium in hypotonic and isotonic solutions. J. Gen. Microbiol. 31, 267-280.

Moissl, C., Bruckner, J.C. \& Venkateswaran, K. (2008). Archaeal diversity analysis of spacecraft assembly clean rooms. ISME J. 2, 115-119.

Mottl, M.J., Glazer, B.T., Kaiser, R.I. \& Meech, K.J. (2007). Water and astrobiology. Chem. Erde. 67, 253-282.

Mullakhanbhai, M.F. \& Larsen, H. (1975). Halobacterium volcanii spec. nov., a Dead Sea halobacterium with a moderate salt requirement. Arch. Microbiol. 104, 207-214.

NASA. (1980). NASA Standard Procedures for the Microbiological Examination of Space Hardware. NPG 5340.1b, NASA, Washington, DC.

Nesbitt, H.W. (2004). Groundwater evolution, authigenic carbonates and sulfates, of the Basque Lake No. 2 basin, Canada. In FluidMineral Interactions: A Tribute to H.P. Eugster, Special Publication, ed. Spencer, R.J. \& Chou, I.-M., vol. 2, pp. 355-371. Geochemical Society, San Antonio, TX, 1990

Onishi, H., Fuchi, H., Konomi, K., Hidaka, O. \& Kamekura, M. (1980). Isolation and distribution of a variety of halophilic bacteria and their classification by salt-response. Agric. Biol. Chem. 44, 1253-1258.

Porazka, T., Kilmer, B.R., Wichita High School Northwest Team, Wichita Northeast Magnet High School Team \& Schneegurt, M.A. (2011). Inland oligohaline soils as a habitat for culturable halotolerant bacteria. Trans. KS Acad. Sci. 115, 170.

Postberg, F., Schmidt, J., Hillier, J., Kempf, S. \& Srama, R. (2011). A saltwater reservoir as the source of a compositionally stratified plume on Enceladus. Nature 474, 620-622.

Probst, A., Vaishampayan, P., Osman, S., Moissl-Eichinger, C., Anderson, G.L. \& Venkateswaran, K. (2010). Diversity of anaerobic microbes in spacecraft assembly clean rooms. Appl. Environ. Microbiol. 76, 2837-2845.

Puleo, J.R., Fields, N.D., Bergstrom, S.L., Oxborrow, G.S., Stabekis, P.D. \& Koukol, R. (1977). Microbiological profiles of the Viking spacecraft. Appl. Environ. Microbiol. 33, 379-384. 
80

Brian R. Kilmer et al.

Schloss, P.D., Westcott, S.L., Ryabin, T., Hall, J.R., Hartmann, M., Hollister, E.B., Lesniewski, R.A., Oakley, B.B., Parks, D.H., Robinson, C.J. et al. (2009). Introducing MOTHUR: open-source, platform-independent, community-supported software for describing and comparing microbial communities. Appl. Environ. Microbiol. 75, 7537-7541.

Schneegurt, M.A. (2012). Media and conditions for the growth of halophilic and halotolerant bacteria and archaea. In Advances in Understanding the Biology of Halophilic Microorganisms, ed. R.H. Vreeland, pp. 35-58. Springer, Dordrecht.

Stieglmeier, M., Wirth, R., Kminek, G. \& Moissl-Eichinger, C. (2009). Cultivation of anaerobic and facultatively anaerobic bacteria from spacecraft-associated clean rooms. Appl. Environ. Microbiol. 75, 3484-3491.

Swofford, D.L. (1998). PAUP*. Phylogenetic Analysis Using Parsimony ( ${ }^{*}$ and Other Methods). Sinauer Associates, Sunderland, MA.

Thompson, J.D., Higgins, D.G. \& Gibson, T.J. (1994). CLUSTAL W: improving the sensitivity of progressive multiple sequence alignment through sequence weighting, position-specific gap penalties and weight matrix choice. Nucleic Acids Res. 22, 4673-4680.

Tosca, N.J., Knoll, A.H. \& McLennan, S.M. (2008). Water activity and the challenge for life on early Mars. Science 320, 1204-1207.

Valenzuela-Encinas, C., Neria-González, I., Alcántara-Hernández, R.J., Estrada-Alvarado, I., Zavala-Díaz de la Serna, F.J., Dendooven, L. \&
Marsch, R. (2009). Changes in the bacterial populations of the highly alkaline saline soil of the former lake Texcoco (Mexico) following flooding. Extremophiles 13, 609-621.

Venkateswaran, K., Satomi, M., Chung, S., Kern, R., Koukol, R., Basic, C. \& White, D. (2001). Molecular microbial diversity of a spacecraft assembly facility. Syst. Appl. Microbiol. 24, 311-320.

Venkateswaran, K., Kempf, M., Chen, F., Satomi, M., Nicholson, W. \& Kern, R. (2003a). Bacillus nealsonii sp. nov., isolated from a spacecraft assembly facility, whose spores are gamma-radiation resistant. Int. J. System. Evol. Microbiol. 53, 165-172.

Venkateswaran, K., Hattori, N., La Duc, M.T. \& Kern, R. (2003b). ATP as a biomarker of viable microorganisms in clean-room facilities. J. Microbiol. Methods 52, 367-377.

Vreeland, R.H. \& Martin, E.L. (1980). Growth characteristics, effects of temperature, and ion specificity of the halotolerant bacterium Halomonas elongata. Can. J. Microbiol. 26, 746-752.

Wani, A.A., Surakasi, V.P., Siddharth, J., Raghavan, R.G., Patole, M.S., Ranade, D. \& Shouche, Y.S. (2006). Molecular analyses of microbial diversity associated with the Lonar soda lake in India: an impact crater in a basalt area. Res. Microbiol. 157, 928-937.

Wänke, H., Brückner, G., Dreibus, G., Rieder, R. \& Ryabchikov, I. (2001). Chemical composition of rocks and soils at the Pathfinder site. Space Sci. Rev. 96, 317-330.

https://doi.org/10.1017/S1473550413000268 Published online by Cambridge University Press 